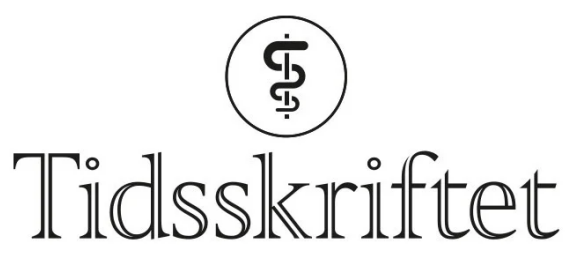

DEN NORSKE LEGEFORENING

\title{
Tor Ole Klemsdal svarer:
}

BREV TIL REDAKTØREN

TOR OLE KLEMSDAL

Tor Ole Klemsdal (f. 1958) er avdelingsoverlege ved Avdeling for preventiv kardiologi, Medisinsk klinikk, Oslo universitetssykehus. Ingen oppgitte interessekonflikter. Email: tor.ole.klemsdal@vikenfiber.no

Erik Arnesen påpeker i sin kommentar at en ny oversiktsartikkel viser at kostens energitetthet er av betydning for vektutviklingen (1). Denne artikkelen gir en god oversikt over de aktuelle studier. Men om man ser på tallene i de studiene som er omtalt, finner man likevel at effekten er så liten at utsagnet i min kronikk om at dette har liten betydning står ved lag. Den desidert største kontrollerte studien viste at en $25 \%$ reduksjon i energitetthet ga ca. o,75 kg lavere vekt etter ett års intervensjon, mens en resterende forskjell på $15 \%$ i energitetthet etter fire år ga ca. o,3 kg vektforskjell, som ikke lenger var signifikant $(\underline{2})$. Den største observasjonsstudien $(n=89432)$ viste ikke signifikant forskjell i vekt (men noe forskjell i livvidde) (3). Den nest største $(\mathrm{n}=50$ 026) fant etter multivariat analyse en vektøkning over åtte år på 4,59 kg hos kvintilen med lavest energitetthet versus $6,44 \mathrm{~kg}$ hos kvintilen med høyest energitetthet (4.), mens den tredje med solid størrelse ( $\mathrm{n}=$ 48 631) ikke rapporterte differanser i kilo, men en mindre effekt på livvidde (5). Selv om det altså i store tallmaterialer kan påvises en signifikant relasjon mellom matens energitetthet og vektendring, synes den kliniske betydningen høyst begrenset.

Tor Ole Kjellevand argumenterer i sin kommentar med at nedgangen i koronar hjertesykdom inntraff før statinene kom i bruk og at nedgang i røyking har vært viktigst. I min artikkel er imidlertid ikke statiner omtalt overhodet, men betydningen av kostendringer som ga reduksjon i befolkningens gjennomsnittlige kolesterolnivå er fremhevet, i tråd med konsistente observasjoner fra våre nordiske naboland. Kjellevand skriver ellers at det i kronikken hevdes at ingen studier har vist bedre effekt av karbohydratfattig kost etter seks måneder, selv om det helt korrekt foreligger enkeltstudier med slike resultater. Det jeg hevder, er imidlertid at det samlet sett ikke er holdepunkter for et nevneverdig større vekttap, slik dette fremkommer i metaanalysen som kronikken referer til.

\section{LITTERATUR}

1. Pérez-Escamilla R, Obbagy JE, Altman JM et al. Dietary energy density and body weight in adults and children: a systematic review. J Acad Nutr Diet 2012; 112: 671-84. [PubMed] 
2. Saquib N, Natarajan L, Rock CL et al. The impact of a long-term reduction in dietary energy density on body weight within a randomized diet trial. Nutr Cancer 2008; 60:31-8. doi:

10.1080/01635580701621320 [PubMed]

3. Du H, van der A DL, Ginder V et al. Dietary energy density in relation to subsequent changes of weight and waist circumference in European men and women. PLoS One 2009; 4: e5339. [PubMed]

4. Bes-Rastrollo M, van Dam RM, Martinez-Gonzalez MA et al. Prospective study of dietary energy density and weight gain in women. Am J Clin Nutr 2008; 88: 769-77. [PubMed]

5. Romaguera D, Angquist L, Du H et al. Dietary determinants of changes in waist circumference adjusted for body mass index - a proxy measure of visceral adiposity. PLoS One 2010; 5: e11588. [PubMed]

Publisert:19. mars 2013. Tidsskr Nor Legeforen. DOI:10.4045/tidsskr.13.0277

(C) Tidsskrift for Den norske legeforening 2023. Lastet ned fra tidsskriftet.no 26. april 2023. 